\title{
Professor David Earnest Poswillo
}

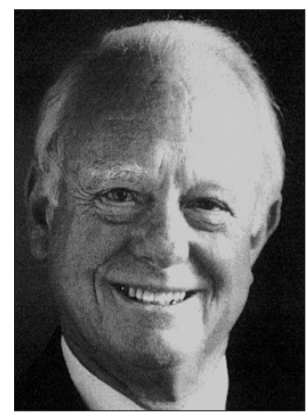

David Poswillo, who died in London in June 2003, was born in Gisborne, New Zealand, in 1927 and graduated in Dentistry at the University of Otago in 1948. He obtained the Fellowship in Dental Surgery from the Royal College of Surgeons in England in 1951, returning to a post in Oral and Maxillofacial Surgery at the Plastic Surgery Unit in Christchurch. He was discovered there by Sir Harold Himsworth, then Secretary of the Medical Research Council in the UK, conducting research in his garden shed on cleft lip and palate! That was the beginning of a tremendously dedicated and successful career as an experimental scientist and innovative surgeon, with a rapidlyachieved and long-sustained international reputation. The Royal College of Surgeons established a Chair in Teratology especially for him, which he occupied for eight years from the late 1960's, combining work at the College's research farm adjacent to Charles Darwin's House in Kent with clinical work at the famous East Grinstead Centre for Maxillofacial and Plastic Surgery. He was an inspiring teacher and many of today's leaders in the field were trained by him at this time. Two years followed as Professor of Craniofacial Surgery in Adelaide, and then from 1979 as Professor of Oral Surgery at the Royal Dental Hospital in London - moving to Guy's when those institutions merged in 1986, until his 'retirement' in 1992.

He went on making seminal contributions. He was always in demand around the world as a lecturer, as a wise officer of many national and international professional organisations, and as an advisor to government in several countries. Outstanding amongst the latter was his leadership of the Department of Health for England Working Party on Anaesthesia, Sedation and Resuscitation in Dental Practice (which produced the 'Poswillo Report' in 1990) and the Scientific Committee on Tobacco and Health, which reported in 1999. The former led rapidly to new procedures and vastly improved safety for dental anaesthesia. The latter led to battles with industry and to hard bargaining with government. Both were pursued with dedi-
Wherever he and his family lived they became pillars of their community. He was a good and loyal friend, a wise counsellor and an inspiration as a scientist.

cation, a hard evidence base, and much charm. The enormous advances in health policy on tobacco issues which we are now seeing in Britain are built to a large extent upon the SCOTH Report of 1998.

Amongst the many offices he held was a spell as Chairman of the UK Committee of the Royal Australasian College of Dental Surgeons, where he worked hard and effectively to maintain a high standard of scientific meetings whilst, with Elizabeth always at his side, he ensured hospitable and always dignified social occasions for that College.

He worked tirelessly as a trustee of the Hunterian Collection at the Royal College of Surgeons from 1994. He was a staunch supporter of the Royal Society of Medicine, serving as President of the Section of Odontology, with many years on Section Council, an elected member of Council of the Society, Honorary Treasurer of the Society from 1996-1999 and Vice President 1999-2001.

Wherever he and his family lived they became pillars of their community. He was a good and loyal friend, a wise counsellor and an inspiration as a scientist. In his last years he bore increasing physical difficulty with determination. When Elisabeth developed a fatal illness and passed away his own health rapidly deteriorated. A simple and immensely moving Memorial Service was held at Guy's Hospital Chapel on 16th October 2003. Two of his four children and two of six grandchildren were present and the Chapel was packed to the top of the Gallery, a clear indication of the esteem in which he was held by a wide range of professional colleagues, neighbours and friends. He is especially missed by his children and grandchildren.

Newell Johnson

\section{Robert Brian Charter}

'Bob', who died from lymphonia in June this year was an outstanding generalist. He had the ability to take the broader view whilst being a stickler for detail. This required patience and dedication to see things through which he invariably did. Early in his career he saw the need for better education for the "chairside assistant' and with true altruism established a local course, teaching and examining, eventually as Chairman of the National Board.

Educated at Guy's Hospital Dental School 1956-62, he qualified BDS and LDS and became house surgeon to Allen Thompson. From this, oral surgery and anaesthesia became special interests in practice and he was an early member of SAAD. In the early 60's, his patients benefited from sedation, surgery, conservation and endotracheal intubation by an anaesthetist in a purpose built practice he helped to build. With the advent of fluoride, he adopted a preventative approach and successfully saw a dramatic reduction in interference dentistry in the families of succeeding generations of patients.

\section{...he switched to sailing off the Sussex} Coast when not playing rugby. His frequent injuries were sorted out on Monday mornings until he agreed to become a referee!

A keen pot holer and climber, he switched to sailing off the Sussex Coast when not playing rugby. His frequent injuries were sorted out on Monday mornings until he agreed to become a referee!

His funeral took place in a packed church with standing room only, full of friends, colleagues, staff and patients, a fitting tribute and some consolation to his widow, Jean and his family who survive him.

Tom Sholl 